\title{
Administration of acetylsalicylic acid after parturition in lactating dairy cows under certified organic management: Part I. Milk yield, milk components, activity patterns, fertility, and health
}

\author{
A. A. Barragan, ${ }^{1 *}$ L. Bauman, ${ }^{2}$ L. da Costa, ${ }^{1}$ J. Velez, ${ }^{3}$ J. D. Rozo Gonzalez, ${ }^{3}$ G. M. Schuenemann, ${ }^{1}$ \\ B. Menichetti, ${ }^{1}$ J. Piñeiro, ${ }^{1} \dagger$ and S. Bas ${ }^{1} \pm \S$ \\ ${ }^{1}$ Department of Veterinary Preventive Medicine, The Ohio State University, Columbus 43210 \\ ${ }^{2}$ Department of Animal Sciences, The Ohio State University, Columbus 43210 \\ ${ }^{3}$ Aurora Organic Farms, Boulder, CO 80302
}

\begin{abstract}
Parturition is a natural process that gradually progresses from one stage to the next. However, around $5 \%$ of dairy cows will experience dystocia, which is considered to be a painful and stressful event. Studies have reported positive effects on cow performance and welfare after treatment with nonsteroidal antiinflammatory drugs during the first postpartum days. The objectives were to assess the effects of acetylsalicylic acid administration after calving on (1) milk yield and components, (2) daily activity patterns, (3) reproductive performance, and (4) health in lactating dairy cows under certified organic management. Cows from 3 organic herds were enrolled. Within 12 $\mathrm{h}$ after parturition, cows were blocked by parity and calving ease and randomly assigned to 2 treatments: (1) aspirin (ASP; $n=278)$, in which cows received 4 consecutive treatments every $12 \mathrm{~h}$ with acetylsalicylic acid (100 mg/kg; 2 boluses) or (2) placebo (PLC, n $=285)$, in which cows received 4 treatments every 12 $\mathrm{h}$ with gelatin capsules (2 capsules) filled with water. Daily milk yield for the first $30 \mathrm{~d}$ in milk (DIM) and monthly milk yield, fat, protein, and somatic cell count (SCC) data from the first 5 Dairy Herd Improvement Association tests were collected. Activity patterns were measured using activity data loggers in the first 7 DIM. Clinical disease events (60 DIM) and fertility data were collected from on-farm computer records. Statistical analysis was performed using the MIXED (milk yield,
\end{abstract}

Received February 18, 2020.

Accepted July 21, 2020.

*Current address: Department of Veterinary and Biomedical Sciences, Pennsylvania State University, University Park 16802.

†Current address: Texas A\&M AgriLife Research and Extension Center, Amarillo 79106.

¥Current address: Phytobiotics Futterzusatzstoffe GmbH, D-65343 Eltville, Germany.

§Corresponding author: s.bas@phytobiotics.com components, and activity), LIFETEST (fertility), and GLIMMIX (health) procedures of SAS (SAS Institute Inc., Cary, NC). Overall, ASP cows produced $1.82 \mathrm{~kg} / \mathrm{d}$ more milk than PLC cows during the first 30 DIM. Interestingly, cows that experienced dystocia and received ASP produced $4.48 \mathrm{~kg} / \mathrm{d}$ more milk compared with cows in the PLC group that experienced dystocia. Cows treated with ASP had lower somatic cell count during the first 5 Dairy Herd Improvement Association tests. There were no differences in daily lying time, lying bouts, and lying bout duration between the ASP and PLC groups. However, cows in the ASP group had 587,64 steps/d more compared with PLC cows. In addition, ASP cows tended to require fewer days (ASP = $113.76 \pm 4.99 \mathrm{~d} ; \mathrm{PLC}=125.36 \pm 4.74 \mathrm{~d})$ and needed fewer services $(\mathrm{ASP}=1.86 \pm 0.21$ services; PLC $=$ $2.19 \pm 0.24$ services) to become pregnant compared with PLC cows. There were no differences in clinical disease events between treatments. Results from this study suggest that treating cows with ASP after calving may help improve milk yields and udder health, increase activity, and enhance fertility in dairy cattle under certified organic management.

Key words: calving, aspirin, milk production, behavior

\section{INTRODUCTION}

Calving is a crucial event that is necessary to produce the next generation of replacement heifers and ensure human food supply and the profitability of dairy farms. Although most cows experience unassisted births, occasionally prolonged calving or the need for assisted extraction of the calf occur, a condition known as dystocia (DYS; Mee, 2008). The incidence of DYS has decreased over the last years, probably due to improvements in management and genetics. In 2006, the National Animal Health Monitoring System reported that $17.5 \%$ of all calvings were dystocic, whereas in 2014 the reported incidence decreased to $4.7 \%$ (USDA, 
2007, 2014). Although better management may be aiding in decreasing the incidence of dystocic births, dairy cows that experience DYS have decreased productive and reproductive performance and increased risk of diseases, which negatively affects welfare and productivity (Lombard et al., 2007; Mee, 2008; Laven et al., 2009).

Parturition, regardless the degree of difficulty, is considered to be one of the most painful events that dairy cattle experience (Huxley and Whay, 2006). In a recent survey performed in the United Kingdom, veterinarians rated DYS as having a high pain score (average $=7$; 10-point scale; Remnant et al., 2017), emphasizing the need to identify animals in need of treatment to ensure optimal animal welfare. Cows that experienced DYS have increased frequency of behaviors that might be associated with pain, such as restless behavior (Schuenemann et al., 2011) and decreased feed intake (Proudfoot et al., 2009). However, the effects of DYS on activity patterns in early lactation warrant further research. Furthermore, periparturient cows will experience varying degrees of local and systemic inflammation due to damage of the birth canal, uterine and mammary gland and tissue remodeling, infectious and metabolic diseases, and altered rumen environment, among others (Bradford et al., 2015; Baumgard et al., 2017). This inflammatory state disrupts the partition of nutrients, which are directed toward the immune system in detriment of milk production (Johnson, 1997; Bertoni et al., 2008).

Although in the past the use of pain management in postpartum cattle was an uncommon practice (Huxley and Whay, 2006), this trend appears to be changing. Demands for high-quality animal products in terms of health, safety, and welfare have increased over the last decades (Battini et al., 2014). Moreover, there is an ethical responsibility to care for animals in discomfort. The use of nonsteroidal anti-inflammatory drugs (NSAID) has been proposed as a pain management strategy in postpartum cattle. Remnant et al. (2017) reported that $80 \%$ of veterinarians who participated in a cattle pain treatment survey provided pain treatment to $\geq 50 \%$ of the cases of DYS. However, in the United States, flunixin meglumine is the only FDA-approved NSAID for use in lactating cattle (Coetzee, 2013). Newby et al. (2017) reported that animals treated with flunixin meglumine intravenously at calving had decreased milk yield and increased risk of stillbirth, retained placenta (RFM), and metritis. Nonsteroidal anti-inflammatory drugs act by inhibiting the cyclooxygenase (COX) enzyme. The inducible form of the enzyme, COX-2, leads to the production of the prostaglandins involved in inflammation, pyrexia, and pain. Consequently, NSAID are used because of their antipyretic, analgesic, and anti-inflammatory effects. Aspirin (ASP) is a weak inhibitor of both COX isoforms; however, its beneficial effects are attributed to the inhibition of COX-2 and preventing the activation of the nuclear factor kappa $\mathrm{B}$ and, thus, the cascade of events leading to the production of proinflammatory cytokines (Vane and Botting, 1997; Kutuk and Basaga, 2004). Furthermore, ASP milk and meat withholdings are shorter than those with other NSAID, and ASP is practical to administer and economical (Smith et al., 2008).

Acetylsalicylic acid and its derivatives have been proposed to decrease inflammation after calving. In a recent study in which sodium salicylate was administrated to dairy cows in the drinking water for $7 \mathrm{~d}$ after parturition, the authors reported that cows in third lactation or greater had increased milk production and fat compared with controls (Farney et al., 2013b). Supporting the latter, Carpenter et al. (2016) reported that cows treated with sodium salicylate and meloxicam (MEL) during the first $3 \mathrm{~d}$ after calving produced more milk and protein compared with untreated controls. However, the effects of a shorter and practical treatment strategy warrant further research. Considering the beneficial effects of ASP, further research is required to evaluate its effects in larger scale studies.

The objective was to assess the effects of oral administration of ASP following parturition on milk yield, milk components (protein, fat, and SCC), daily activity patterns, reproductive performance, and health of lactating dairy cows under certified organic management. A secondary objective was to evaluate activity patterns and milk yield based on parity and calving ease of lactating dairy cows under certified organic management. We hypothesized that cows treated with acetylsalicylic acid would have increased milk yield and components (fat and protein), decreased SCC, altered activity patterns, and improved reproduction compared with placebo cows.

\section{MATERIALS AND METHODS}

\section{Animals, Facilities, and Feeding}

This study was performed between May and July 2016 in 3 organic dairy farms in Colorado. Herds A and B milked approximately 3,000 cows, and herd C milked approximately 5,300 cows. All farms had a similar management and similar genetic basis, shared the same TMR, and were located within a $500-\mathrm{m}$ radius. Milk yield averaged 8,875, 8,953, and 9,758 $\mathrm{kg}$ for farms A, B, and C, respectively. Pregnant cows were dried off at $60 \pm 3 \mathrm{~d}$ before their expected calving date and were moved into a far-off dry pen. At $21 \pm 3$ d before parturition, cows and pregnant heifers were moved to prepartum pens in a common maternity facility. The 
prepartum pens consisted of loose pens with wood shavings as bedding material and free access to a contiguous dry lot.

The farm personnel monitored the prepartum pens approximately every hour looking for animals showing imminent signs of calving (e.g., rupture of allantoidal membrane, amniotic sac or feet of the calf outside the vulva). Cows in labor were closely monitored by farm personnel, and if signs of difficult calving were observed, the animals received proper assistance. After parturition, farm personnel followed the farm standard operating procedures for postpartum cows (e.g., physical examination, collection and assessment of colostrum quality).

Within $1 \mathrm{~d}$ after parturition, postpartum cows were moved to their respective farms. Fresh cows were housed on sand-bedded 6-row freestall barns with access to a contiguous dry lot for approximately $30 \mathrm{~d}$. Postparturient cows were milked 3 times daily at approximately 8-h intervals, had free access to water, and shared a TMR formulated to meet or exceed dietary nutritional requirements for high-producing lactating dairy cows (Table 1; NRC, 2001). Fresh feed was delivered twice daily, and feed was pushed up at approximately 1-h intervals. Furthermore, during the study period, dairy fresh cows were allowed to graze on a pasture (mixture of alfalfa, ryegrass, and orchard grass as well as triticale, wheat, and sorghum). Dairy farms kept individual animal records regarding health, reproduction, and production using a computerized on-farm record-keeping systems (PCDART, Dairy Records Management Systems, Raleigh, NC). The procedures described below were revised and accepted by the Institutional Animal Care and Use Committee at The Ohio State University (protocol no. 2016A00000045).

\section{Animal Enrollment and Allocation to Treatments}

Twice a week (Mondays and Wednesday), within 12 $\mathrm{h}$ after delivery, postpartum cows were enrolled in the study (study d 1). A total of 563 cows were enrolled in the present study. Cows were blocked by calving ease [DYS or eutocia (EUT)] and parity [primiparous (PRIM) or multiparous (MULT)] and were randomly allocated to 2 treatment groups. In the acetylsalicylic acid (ASP) treatment $(\mathrm{n}=278)$, cows received 4 consecutive treatments every $12 \mathrm{~h}$ with acetylsalicylic acid (100 mg/kg; 2 boluses; Agri Labs, St. Joseph, MO). In the placebo $(\mathbf{P L C})$ treatment $(\mathrm{n}=285)$, cows received 4 treatments every $12 \mathrm{~h}$ with gelatin capsules (2 capsules; Torpac Inc., Fairfield, NJ) filled with water. The first treatment was performed in the maternity facility, whereas the subsequent treatments were administered in the postpartum pens. Briefly, after the morning and afternoon milkings, cows were restrained using the headlocks on the postpartum pens, and treatment was administered by the study team (AB and $\mathrm{LB}$ ).

Calving ease (degree of assistance provided at birth) was assessed by farm personnel using a 5-point scale adapted from Lombard et al. (2007), where $1=$ unassisted, 2 = assistance from 1 person, $3=$ assistance from 2 or more people, $4=$ mechanical traction assistance, and $5=$ surgical procedure. Cows recorded with a calving ease score of $\leq 2$ were classified as having experienced EUT, whereas cows recorded with a calving ease score of $\geq 3$ were classified as having experienced DYS. Cows that experienced a fetotomy or caesarean section (calving ease score of 5 ) were not included in the present study.

A total of 16 cows $(\mathrm{ASP}=9 ; \mathrm{PLC}=7$ ) were not included in the study due to loss of follow-up during the treatment administration period $(\mathrm{n}=4)$, death $(\mathrm{n}=$ 10), or being sold by the farm $(n=2)$ during the first week of lactation. Furthermore, cows diagnosed by the farm personnel as having a health disorder (e.g., metritis, mastitis) that were treated with aspirin $(\mathrm{ASP}=46$; PLC $=37$ ) in the first week of lactation were removed from the study. Therefore, a total of 464 cows remained in the study $[223$ in the ASP group (MULT EUT = $148 ;$ MULT DYS $=18 ;$ PRIM EUT $=49 ;$ PRIM DYS

Table 1. Ingredient and analyzed chemical composition (\% of DM unless otherwise noted) of prepartum and early-postpartum diets

\begin{tabular}{|c|c|c|}
\hline Item & Prepartum & Postpartum \\
\hline \multicolumn{3}{|l|}{ Ingredient } \\
\hline Sorghum hay & - & 2 \\
\hline Millet hay & - & 2 \\
\hline Grass hay & 10 & 2.50 \\
\hline Alfalfa & 12 & 4.69 \\
\hline Grain premix & 5 & 20.75 \\
\hline Rolled soybean & - & 1.55 \\
\hline Cottonseed & - & 3.00 \\
\hline Corn silage & 10.55 & 16.12 \\
\hline Alfalfa haylage & - & 7.00 \\
\hline Wheat silage & - & 12.00 \\
\hline Close-up mineral & 1 & - \\
\hline \multicolumn{3}{|l|}{ Chemical analysis } \\
\hline $\mathrm{DM}$ & 47.4 & 48.1 \\
\hline Starch & 14.4 & 21.21 \\
\hline $\mathrm{CP}$ & 12.5 & 16.77 \\
\hline NDF & 39.1 & 35.18 \\
\hline $\mathrm{ADF}$ & 30.3 & 23.98 \\
\hline Ether extract & 2.99 & 5.05 \\
\hline Calcium & 1.64 & 0.67 \\
\hline Phosphorus & 0.37 & 0.41 \\
\hline Sulfur & 0.37 & 0.21 \\
\hline Potassium & 1.11 & 2.14 \\
\hline Sodium & 0.27 & 0.25 \\
\hline Chlorine & 0.78 & 0.55 \\
\hline $\mathrm{NE}_{\mathrm{L}}(\mathrm{Mcal} / \mathrm{kg}$ of $\mathrm{DM})$ & 0.65 & 0.71 \\
\hline $\mathrm{DCAD}^{1}(\mathrm{mEq} / 100 \mathrm{~g}$ of DM$)$ & -5.2 & 36.6 \\
\hline
\end{tabular}

${ }^{1}$ Calculated as $(\mathrm{mEq}$ of $\mathrm{Na}+\mathrm{mEq}$ of $\mathrm{K})-(\mathrm{mEq}$ of $\mathrm{S}+\mathrm{mEq}$ of $\mathrm{Cl})$. 
$=8$ ) and 241 in the PLC group (MULT EUT $=162$; MULT DYS $=20 ;$ PRIM EUT $=51 ;$ PRIM DYS $=8]$.

\section{Daily Milk Yield and DHIA Test Milk Yield and Milk Components Yield}

Daily milk yield data were obtained from on-farm computer systems (Alpro Herd Management, DeLaval Inc., Kansas City, MO) for animals in farms A and B $(\mathrm{ASP}=114 ; \mathrm{PLC}=129)$. Briefly, once a week on-farm daily milk yield data were extracted, and information was then uploaded into a Microsoft Excel spreadsheet (Microsoft Corp., Redmond, WA). Furthermore, data from the first 5 DHIA tests relative to calving were obtained from all farms through on-farm computer records (PCDART) to assess differences in milk yield, milk protein yield, milk fat yield, and SCC between treatments groups.

\section{Activity Patterns}

Within each treatment, a subset of cows was randomly assigned to receive an activity data logger (IceQube, IceRobotics, Edinburgh, UK) accounting for parity (PRIM and MULT) and calving ease (EUT and DYS) group, such that activity information would be collected from an approximately equal number of cows within each treatment block. At enrollment, data loggers were placed on the right hind leg of a subset of cows (ASP $=36 ; \mathrm{PLC}=41)$ for assessment of lying time $(\mathbf{L T})$, number of steps (STP), number of lying bouts (LB), and lying bouts duration (LBD). The activity data loggers were removed $7 \mathrm{~d}$ later (7 DIM). Individual cow activity data were extracted using the IceReader into the IceManager software (IceRobotics) in 15-min time blocks (continuous measurement every $15 \mathrm{~min}$ ). Thereafter, daily means were calculated from the raw data and transferred to a Microsoft Excel spreadsheet for further analysis.

\section{Blood Sample Collection and Assessment of BCS and Rectal Temperature}

Blood samples were collected from coccygeal blood vessels at $7 \pm 3$ (study d 7) and $14 \pm 3$ (study d 14) DIM for assessment of BHB concentrations. Serum concentrations of BHB were determined using a NovaVet electronic handheld device (Nova Biomedical Corp., Waltham, MA). A cow was classified as having ketosis when serum BHB concentrations were greater than 1.2 $\mathrm{mmol} / \mathrm{L}$ (Iwersen et al., 2009). Body condition score was assessed using a 5-point scale (Ferguson et al., 1994) at enrollment (study d 1) and at $7 \pm 3$ and $14 \pm$ $3 \mathrm{~d}$ after calving. Rectal temperature was measured im- mediately before each treatment administration using a digital thermometer (Lifeline Medical Devices, Haryana Gurugram, India). A rectal temperature $>39.5 \mathrm{C}^{\circ}$ was considered pyrexia.

\section{Cases of Diseases, and Mortality and Culling Rates}

The incidence of RFM, defined as the failure to expel the placenta by $24 \mathrm{~h}$ after birth (Kelton et al., 1998), was assessed by the research team at the second and consecutive study treatment administrations. The cases of other clinical disease [i.e., digestive disorders (cows with abnormal manure such as fluid or dry feces), lameness (cows that had difficulty walking normally; Van Nuffel et al., 2015), metritis (cows with red-brownish fetid and watery vaginal discharge; Barragan et al., 2018), endometritis (cows with purulent vaginal discharge after 21 DIM; Sheldon et al., 2008), pneumonia (cows that had difficulty breathing normally with pyrexia; Santos et al., 2011), and mastitis (cows that had abnormal milk in at least 1 of the quarters at milking; Santos et al., 2011)] and culling and mortality rates were recorded by farm personnel and obtained from on-farm computer records (PCDART). Briefly, farm personnel performed daily health checks on the fresh cows immediately after the morning milking. Data on diseases, mortality, and culling rates were obtained for the first 60 DIM. Study cows were grouped in 3 groups based on the number of clinical disease events (CDEVT) they experienced during the first 60 DIM (healthy $=331,1$ case of disease $=90,>1$ case of disease $=43$ ).

\section{Farm Reproductive Management and Reproductive Data Collection}

All study cows were subjected to the same reproductive program, which consisted of estrus detection using a combination of tail chalking and visual observation of estrus signs twice a day. The voluntary waiting period was $45 \pm 3 \mathrm{~d}$. Cows that did not get pregnant after an average of 5 services were moved to a pen for natural service with bulls. Days in milk to first service (DIMFS), DIM to conception (DIMC), number of services required to conceive (SPC), pregnancy per AI (PAI) at first service were obtained from on-farm computer records (PCDART).

\section{Statistical Analysis}

To determine the required sample size for this study, a power calculation was performed. To accurately detect a milk yield difference of $1.5 \mathrm{~kg}$ between ASP and PLC treatment groups with adequate statistical power $(1-\beta=0.8)$ and significance $(\alpha=0.05)$, a sample 
size of 253 dairy cows per group (total of 506 animals) was required. The study was conducted as a complete randomized block design. The data were analyzed using SAS statistical software (version 9.4, SAS Institute Inc., Cary, NC). The normality and homogeneity of variances for the quantitative variables were assessed using the UNIVARIATE procedure, Shapiro-Wilk statistic, graphical methods (histogram and quantile-quantile plot), and Bartlett's tests.

Continuous variables (i.e., daily milk yield, DHIA tests, activity patterns, BHB concentrations, BCS, DIMFS, DIMC, and SPC) were analyzed using linear mixed models generated by the MIXED procedure of SAS. For analysis of continuous variables measured at various time points (i.e., daily milk yield, DHIA tests, activity patterns, BHB concentrations, and BCS), the REPEATED statement was included in the MIXED procedure and the treatment by time interaction was forced in the model. The covariate structure for each model was selected based on the best fit according to Schwarz's Bayesian information criteria. The variables DHIA milk protein yield, DIMFS, and SPC were logtransformed due to lack of normality. Multivariable logistic regression was used to analyze the binomial and categorical variables (i.e., pyrexia, ketosis, RFM, CDEVT, mortality rate, culling rate, and PAI at first service) using the GLIMMIX procedure of SAS.

The variables originally offered to the models were treatment (ASP, PLC), time (repeated measure), parity (PRIM, MULT), calving ease (DYS, EUT), farm, week of enrollment, twins, stillbirth, RFM, CDEVT (i.e., healthy, 1 case of disease, $>1$ case of disease), BCS at 7 \pm 3 and $14 \pm 3$ DIM, ketosis at $7 \pm 3$ and $14 \pm 3$ DIM, and sold and died as well as the interactions between these variables and the treatment. The main effect of treatment, time, and their interaction (where appropriate) and the blocking variables (parity and calving ease) were forced into the models. The Wald statistic backward selection criterion $(P>0.15)$ was used to select the variables that remained in the model. The variable cow or cow within farm (in models where farm was not significant) were included in the model as the random effect. The least squares means and standard error of the mean were calculated and adjusted (TukeyKramer method) using the LSMEAN statement and are reported. Transformed data were back-transformed, and results are presented as back-transformed geometric means and $95 \%$ confidence interval. For the analysis of DIMC up to $300 \mathrm{~d}$ of lactation, the PHREG procedure of SAS (i.e., Cox proportional hazard model), controlling for the effects of parity, was used. Data obtained from the SAS output were uploaded into a Microsoft Excel spreadsheet to create a graph that represented the proportion of cows pregnant up to 300 DIM. The variables of interest as well as their interactions were considered significant if $P<0.05$, and $0.05<P<0.10$ was considered a tendency.

\section{RESULTS}

\section{Daily Milk Yield and DHIA Test Milk Yield and Milk Components Yield}

Overall, cows that received ASP produced $1.82 \mathrm{~kg} / \mathrm{d}$ more milk $(P=0.048)$ compared with cows in the PLC group during the first 30 DIM (Figure 1). Furthermore, there was an interaction between treatment, day, and DYS $(P=0.041)$. Cows that experienced DYS and received ASP $(\mathrm{n}=13)$ produced $4.48 \mathrm{~kg} / \mathrm{d}$ more milk compared with DYS cows that received PLC $(\mathrm{n}=17)$, whereas in cows that experienced EUT, treatment with ASP increased $(P<0.05)$ milk production on d 12,15 , 17, and 22 of lactation (Figure 2). Milk yield analysis by DHIA test revealed that cows treated with ASP tended $(P=0.057)$ to produce $1.11 \mathrm{~kg}$ more milk than PLC cows during the first 5 DHIA tests (Figure 3A). However, DHIA milk yield analysis revealed no interactions $(P>0.1)$ in milk production between treatment and calving ease. Overall, there was no difference in milk fat $(\mathrm{ASP}=1.66 \pm 0.02 \mathrm{~kg} ; \mathrm{PLC}=1.64 \pm 0.02$ $\mathrm{kg} ; P=0.53)$ and milk protein $(\mathrm{ASP}=1.30 \pm 0.01 \mathrm{~kg}$; $\mathrm{PLC}=1.30 \pm 0.01 \mathrm{~kg} ; P=0.70)$ in the DHIA tests between groups. In addition, cows treated with ASP had lower $(P=0.03)$ SCC during the first 5 DHIA tests compared with PLC cows (ASP $=87,116$ cells $/$ $\mathrm{mL} ; \mathrm{PLC}=130,137$ cells/mL; Figure 3B).

\section{Activity Patterns}

Overall, there was no difference in $\mathrm{LT}, \mathrm{LB}$, and $\mathrm{LBD}$ between cows in the ASP and PLC groups (Table 2). However, there was a treatment by day interaction, and cows treated with aspirin tended $(P=0.08)$ to spend less time lying down $(\mathrm{ASP}=452.81 \pm 24.82 \mathrm{~min} / \mathrm{d}$; $\mathrm{PLC}=510.96 \pm 23.70 \mathrm{~min} / \mathrm{d})$ and tended $(P=0.06)$ to have shorter $\mathrm{LBD}(\mathrm{ASP}=36.90 \pm 3.20 \mathrm{~min} ; \mathrm{PLC}=$ $44.99 \pm 3.05 \mathrm{~min}$ ) during the first day after parturition compared with PLC cows. Nevertheless, cows in the ASP group had more STP compared with cows in the PLC group $(P=0.002 ; \mathrm{ASP}=3,850 \pm 155$ steps $/ \mathrm{d} ; \mathrm{PLC}=$ $3,262 \pm 148$ steps/d; Table 2; Figure 4). Regardless of treatment, cows that experienced DYS spent more time lying $(P=0.01 ; \mathrm{DYS}=564.66 \pm 18.24 \mathrm{~min} / \mathrm{d} ; \mathrm{EUT}=$ $503.91 \pm 17.23 \mathrm{~min} / \mathrm{d})$, had fewer STP $(P=0.03$; DYS $=3,328 \pm 157$ steps $/ \mathrm{d} ;$ EUT $=3,784 \pm 147$ steps $/ \mathrm{d})$, had more LB $(P=0.01 ;$ DYS $=12 \pm 0.58$ bouts $/ \mathrm{d}$; EUT $=10 \pm 0.55$ bouts $/ \mathrm{d})$, and had shorter LBD $(P$ $=0.04 ; \mathrm{DYS}=49.07 \pm 2.03 \mathrm{~min} ; \mathrm{EUT}=54.79 \pm 1.91$ 
min) than EUT cows (Table 2; Figure 5). Furthermore, the activity patterns by days relative to calving in cows that experienced DYS or EUT are shown in Figure 5. Analysis by parity showed that PRIM cows spent less time lying $(P<0.001 ; \mathrm{PRIM}=486.37 \pm 20.35 \mathrm{~min} / \mathrm{d}$; MULT $=582.21 \pm 15.37 \mathrm{~min} / \mathrm{d})$ and had more STP $(P$ $=0.001 ;$ PRIM $=3,902 \pm 176$ steps $/ \mathrm{d} ;$ MULT $=3,210$ \pm 132 steps/d) compared with MULT cows regardless of treatment (Table 2; Figure 6). Figure 6 shows LT and STP by days after calving.

\section{BCS, Pyrexia, BHB Concentration, and Subclinical Ketosis}

Cows treated with ASP tended to have and had higher BCS on $7 \pm 3 \mathrm{~d}(P=0.07$; $\mathrm{ASP}=2.74 \pm 0.06$; $\mathrm{PLC}=2.66 \pm 0.06)$ and $14 \pm 3 \mathrm{~d}(P=0.01 ; \mathrm{ASP}=$ $2.64 \pm 0.06 ; \mathrm{PLC}=2.54 \pm 0.06)$ after calving, respectively, compared with PLC cows (Table 3). There was no difference in the proportion of cows with pyrexia between treatment groups (pyrexia $12 \mathrm{~h}: \mathrm{ASP}=3.86$ $\pm 1.34 \%, \mathrm{PLC}=3.63 \pm 1.26 \%, P=0.90 ;$ pyrexia 24 $\mathrm{h}: \mathrm{ASP}=6.29 \pm 2.06 \%, \mathrm{PLC}=5.29 \pm 1.85 \%, P=$ 0.71 ; pyrexia $36 \mathrm{~h}$ : $\mathrm{ASP}=3.52 \pm 1.32 \%, \mathrm{PLC}=1.82$ $\pm 0.90 \%, P=0.28$; pyrexia $48 \mathrm{~h}: \mathrm{ASP}=5.77 \pm 1.99 \%$, $\mathrm{PLC}=8.78 \pm 2.35 \%, P=0.33$; Table 3 ). In addition, there were no differences between ASP and PLC groups in BHB concentrations $(7 \pm 3$ DIM: ASP $=0.95 \pm 0.09$ $\mathrm{mmol} / \mathrm{L}, \mathrm{PLC}=0.97 \pm 0.10 \mathrm{mmol} / \mathrm{L}, P=0.72 ; 14 \pm$ 3 DIM: ASP $=0.73 \pm 0.10 \mathrm{mmol} / \mathrm{L}, \mathrm{PLC}=0.72 \pm$ $0.10 \mathrm{mmol} / \mathrm{L}, P=0.89$; Table 3$)$ or in the proportion of cows with subclinical ketosis on study d 7 and $14(7 \pm$ 3 DIM: $\mathrm{ASP}=16.59 \pm 3.90 \%, \mathrm{PLC}=16.92 \pm 3.96 \%$, $P=0.92 ; 14 \pm 3$ DIM: $\mathrm{ASP}=4.83 \pm 2.06 \%$, PLC $=$ $4.54 \pm 2.40 \%, P=0.82$; Table 3 ).

\section{Fertility, Cases of Clinical Diseases, Mortality, and Culling Rates}

Cows treated with ASP tended $(P=0.05)$ to receive the first service sooner compared with PLC cows (ASP $=83.42 \pm 19.75 \mathrm{~d} ;$ PLC $=107.74 \pm 32.87 \mathrm{~d})$. Furthermore, ASP-treated cows tended to require fewer DIM $(P=0.07 ; \mathrm{ASP}=113.76 \pm 4.99 \mathrm{~d} ; \mathrm{PLC}=125.36 \pm$ $4.74 \mathrm{~d}$; Figure 7) and needed fewer services to conceive $(P=0.04 ; \mathrm{ASP}=1.86 \pm 0.21$ services; PLC $=2.19 \pm 0.24$ services) compared with PLC-treated cows. Although the proportion of cows that became pregnant at the first service was not different in the ASP group compared with the PLC group $(P=0.14$; $\mathrm{ASP}=39.84 \pm 4.43 \% ; \mathrm{PLC}=31.06 \pm 4.03 \%)$, there was a tendency for an interaction between treatment

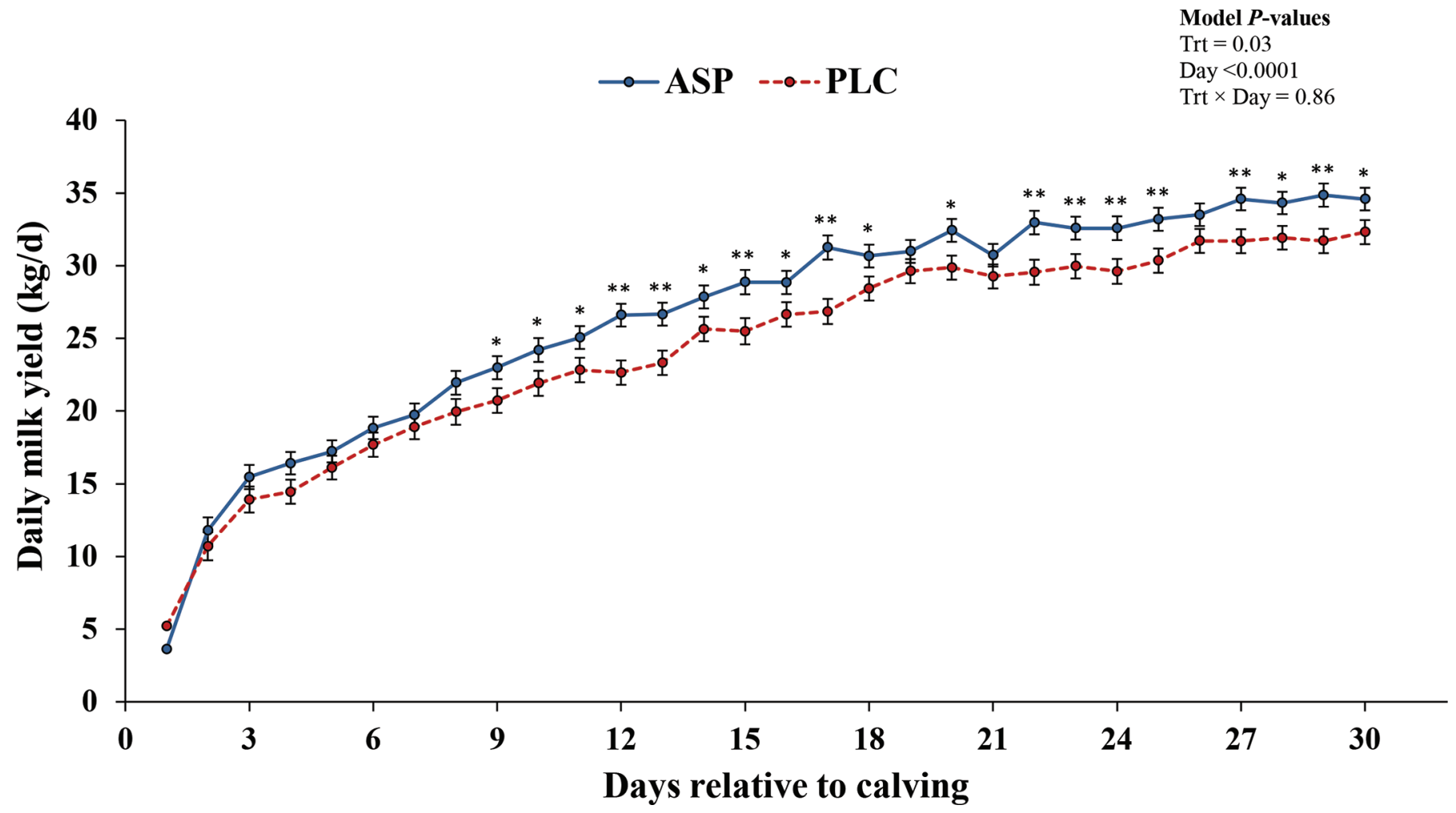

Figure 1. Daily milk production $(\mathrm{kg} / \mathrm{d} ; \mathrm{LSM} \pm \mathrm{SEM})$ of dairy cows treated with acetylsalicylic acid (ASP; $\mathrm{n}=114)$ or a placebo (PLC; $\mathrm{n}$ $=129)$ during the first 30 DIM. ${ }^{*} 0.05<P \leq 0.10 ; * * P<0.05$. $P$-values are from the "slice" option. Trt $=$ treatment. 

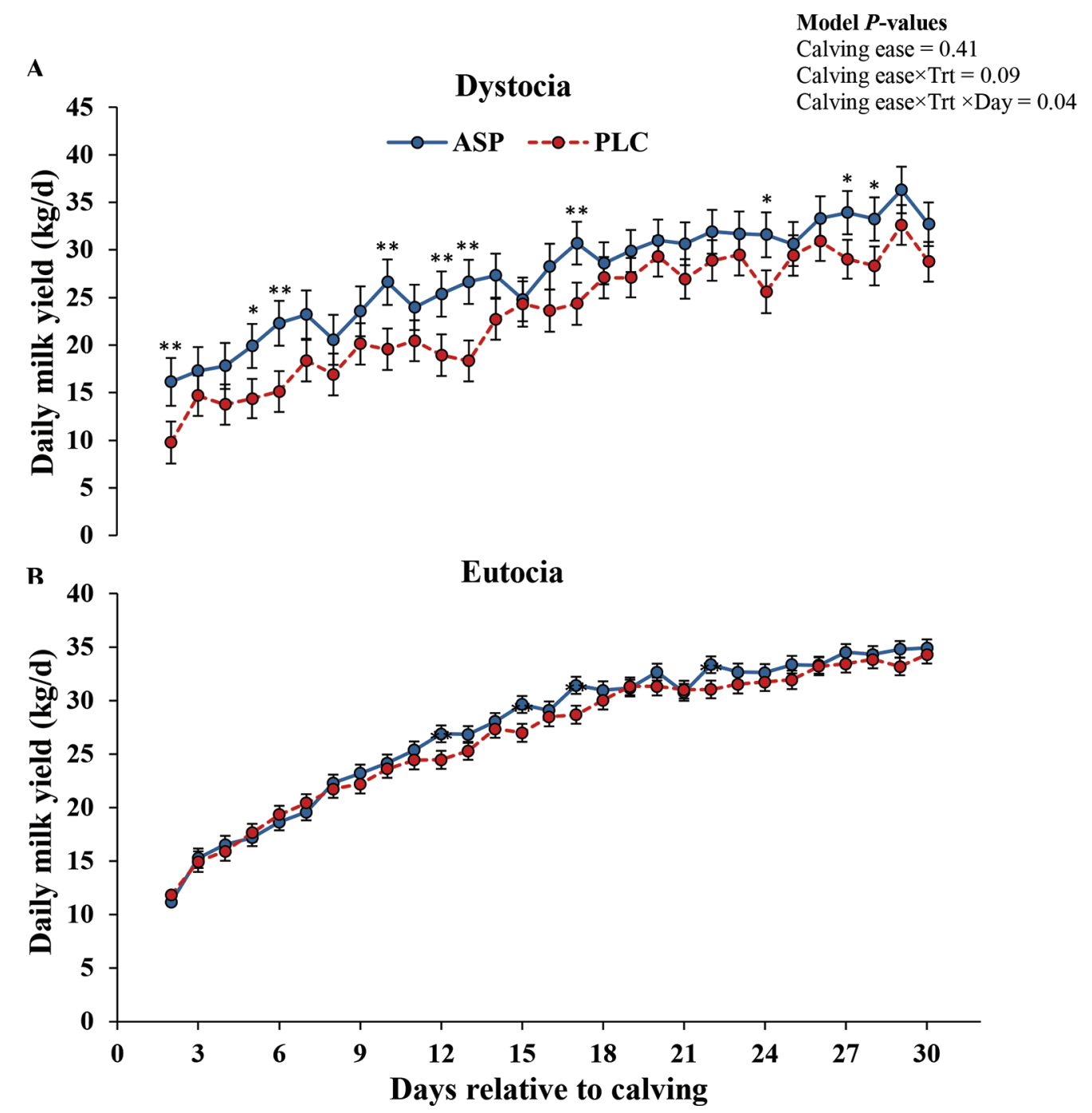

Figure 2. Daily milk yield $(\mathrm{kg} / \mathrm{d} ; \mathrm{LSM} \pm \mathrm{SEM})$ for the first $30 \mathrm{DIM}$ of dairy cows that experienced $(\mathrm{A})$ dystocia $(\mathrm{ASP}=12 ; \mathrm{PLC}=16)$ or $(\mathrm{B})$ eutocia $(\mathrm{ASP}=102 ; \mathrm{PLC}=113)$ and received either acetylsalicylic acid $(\mathrm{ASP})$ or placebo $(\mathrm{PLC})$ treatment. ${ }^{*} 0.05<P \leq 0.10 ;{ }^{* *} P<$ 0.05. P-values are from the "slice" option. Trt $=$ treatment.

and parity $(P=0.10)$. A greater proportion of MULT cows treated with ASP tended to become pregnant at first service compared with MULT cows treated with PLC after calving $(P=0.07 ; \mathrm{ASP}=39.28 \pm 5.37 \%$; $\mathrm{PLC}=26.37 \pm 4.65 \%)$. The proportions of cows that experienced RFM, remained healthy, or developed 1 or more cases of clinical disease (CDEVT) and were culled or died are presented in Table 4 . There were no differences in the incidence of diseases and culling and mortality rates between treatment groups (Table 4).

\section{DISCUSSION}

The present study was designed to assess whether treatment with ASP affected milk yield, milk components, activity patterns, fertility, and health of postpar- tum dairy cows under certified organic management. During the periparturient period, dairy cows experience various degrees of local and systemic inflammation (Bionaz et al., 2007; Trevisi and Bertoni, 2008; Sordillo et al., 2009). This inflammatory state is in part due to damage of the birth canal, tissue remodeling associated with uterine involution and lactogenesis, increased incidence of infectious and metabolic diseases, and excessive mobilization of fat (Drackley, 1999; Bradford et al., 2015). Consequently, proinflammatory cytokines such as tumor necrosis factor- $\alpha$, IL-1 $\beta$, and IL- 6 , which have a wide array of local and systemic effects, are produced (Bradford et al., 2015). Thus, treatment with NSAID after parturition may help decrease the magnitude of the inflammatory response and its negative effects on production (Bertoni et al., 2004). 
Model $P$-values

$\operatorname{Trt}=0.05$

Day $<0.0001$

A

$\operatorname{Trt} \times$ Day $=0.14$

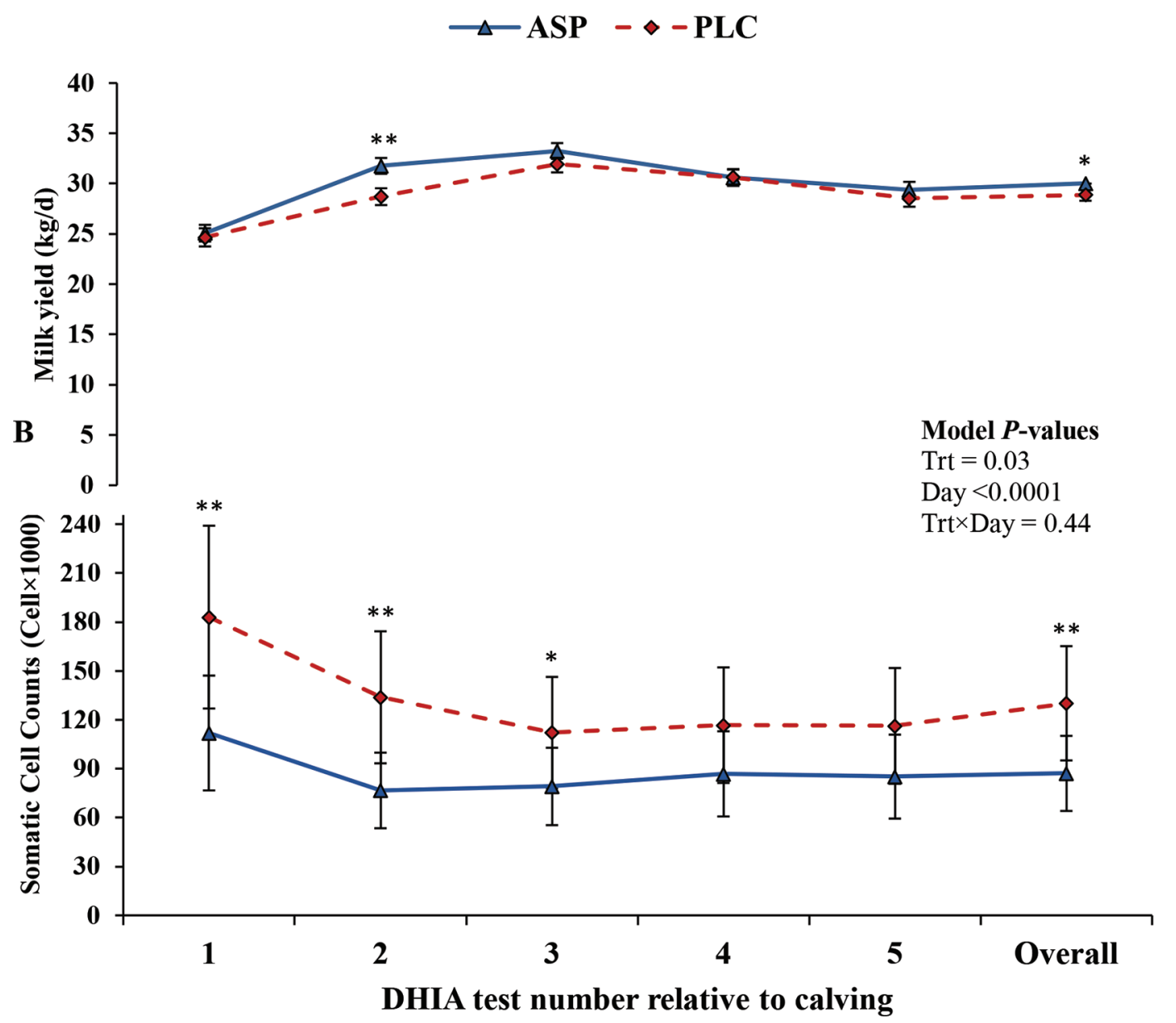

Figure 3. The DHIA test-day (A) milk (LSM \pm SEM) and (B) SCC (back-transformed LSM \pm SEM) for the first 5 DHIA tests of dairy cows that received acetylsalicylic acid (ASP; $\mathrm{n}=189$ ) compared with cows that received a placebo $(\mathrm{PLC} ; \mathrm{n}=208)$. ${ }^{*} 0.05<P \leq 0.10 ;{ }^{*} * P<$ 0.05. $P$-values are from the "slice" option. Trt $=$ treatment.

The improvement in milk yield observed in this study could be in part explained by the anti-inflammatory and analgesic properties of ASP. Nevertheless, some studies (Bertoni et al., 2004; Farney et al., 2013b; Swartz et al., 2018) reported improved milk yield in postpartum dairy cows treated with NSAID, whereas others failed to observe an effect (Newby et al., 2013; Meier et al., 2014; Pascottini et al., 2020) or reported a decrease in milk production (Newby et al., 2017). The differences among these studies may in part be attributed to the NSAID used, the timing of administration relative to calving, treatment duration, dosage, and route of administration. Nevertheless, adverse effects of treating postpartum cows with NSAID have been reported.
Newby et al. (2017) administered flunixin meglumine to cows immediately after parturition and $24 \mathrm{~h}$ later and observed that treated cows had increased odds of RFM and metritis compared with controls. Prostaglandins play a central role in the cascade of events leading to parturition and expulsion of fetal membranes (Laven and Peters, 1996). Treatment with NSAID can reduce prostaglandin synthesis, which can lead to RFM and increased risk of uterine diseases. For this study, a shorter duration treatment strategy (4 treatments 12 $\mathrm{h}$ apart) was assessed with the intention of exploring a more practical approach, and the first ASP treatment was administered by $12 \mathrm{~h}$ after parturition to avoid potential adverse effects. 


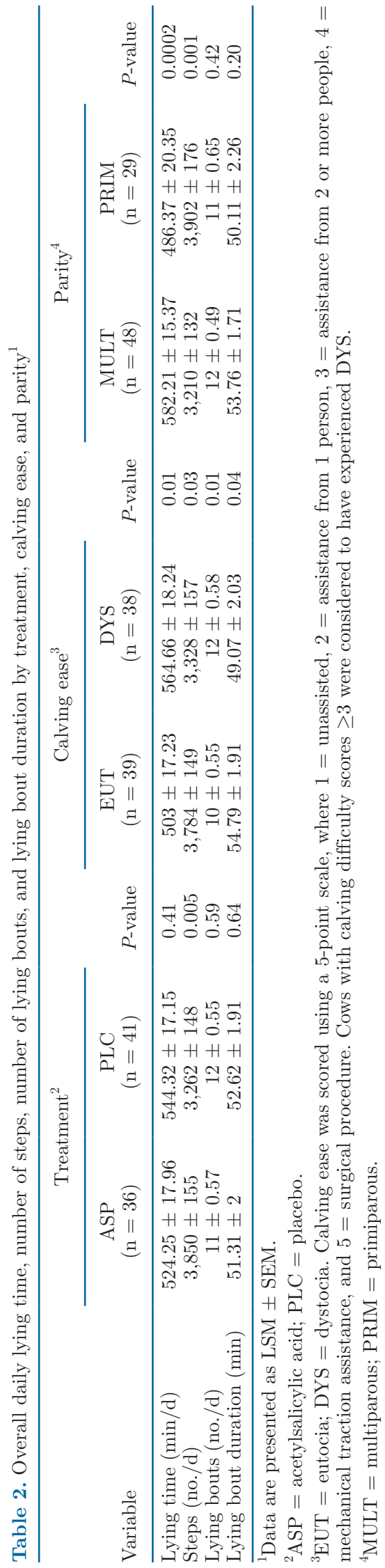

Treatment with ASP resulted in increased daily milk yield for the first 30 DIM and monthly milk yield for the first 5 DHIA milk tests relative to calving compared with PLC cows. Similar findings were observed by Bertoni et al. (2004), who treated dairy cows with acetylsalicylic acid intramuscularly for $5 \mathrm{~d}$ after parturition and reported an increased peak milk yield. Furthermore, Farney et al. (2013b) treated dairy cows with ASP in the drinking water for $7 \mathrm{~d}$ after parturition and observed increased milk yields in treated cows in third lactation or greater compared with controls. Due to the periparturient inflammatory state, more nutrients are redirected from expendable processes such as milk production, reproduction, and fat deposition toward the immune system (Johnson, 1997; Bertoni et al., 2008). In addition, a direct effect of mediators of inflammation in the mammary gland can contribute to the reduced milk yield in control cows. It has been reported that there is a transient surge in the proliferation of mammary gland secretory cells and that the alveolar cell population doubles in size between the last day of pregnancy and 5 DIM (Knight and Peaker, 1982). Recently, Connelly et al. (2010) observed that the activation of nuclear factor kappa B promoted milk losses and apoptosis in the mammary gland epithelium of transgenic mice. Thus, the early postpartum inflammatory state may negatively affect the cellular changes associated with lactogenesis with detrimental effects on milk production. In addition, due to its direct link with milk production, feeding behavior should be considered. In this sense, Newby et al. (2013) concluded that MEL-treated cows spent more time feeding and had increased bunk visits compared with PLC cows. More recently, it was observed that elevated haptoglobin (HP) early in lactation was associated with decreased DMI in dairy cows (McCarthy et al., 2016). Thus, the improvement in milk production observed in this study may in part be explained by a reduction in the mediators of inflammation, which could negatively affect nutrient partitioning, the mammary tissue, and DMI.

Interestingly, cows that experienced DYS had a greater benefit from ASP treatment in terms of milk production compared with EUT cows in the first 30 d of lactation. Domecq et al. (1997) reported an average reduction of $273 \mathrm{~kg}$ of milk in the first 120 DIM in MULT cows that experienced DYS. However, other authors (Swartz et al., 2018) have failed to find differences in milk production in DYS cows treated with an NSAID (i.e., MEL) after calving. The extent of damage to the cervical and vaginal tissues and the degree of inflammation are exacerbated in cows that experience DYS. Supporting the latter, Pohl et al. (2015) reported that MULT cows that experienced assisted births had higher HP concentrations by 5 DIM compared with 
cows that calved spontaneously. Bertoni et al. (2008) categorized cows into inflammatory quartiles and concluded that cows with the strongest inflammatory profile in the first month of lactation had reduced milk yield and more transition disorders. Altogether, DYS cows may have experienced a greater benefit from ASP anti-inflammatory and analgesic effects, which could in part explain the greater response in milk yield observed in DYS cows.

A reduction in SCC was observed in cows treated with ASP compared with PLC cows. Similar findings were observed by Carpenter et al. (2016), who reported that treatment with ASP and MEL resulted in decreased SCC during the first months of lactation. McDougall et al. (2009) reported that treatment of clinical mastitis with a combination of antimicrobials and MEL decreased SCC at 7, 14, and $21 \mathrm{~d}$ after treatment compared with animals treated only with the antibiotic. More recently, an in vitro study showed that treatment with MEL of mammary gland epithelial cells challenged with LPS or lipoteichoic acid reduced the mRNA abundance of inflammatory mediators (Caldeira et al., 2019). Somatic cells migrate into the mammary gland in response to cytokines and other mediators of inflammation; thus, it is reasonable to assume that treatment with NSAID may lead to a reduction in the production of inflammatory mediators, the influx of inflammatory cells to the mammary gland, and, consequently, SCC.
However, more research is needed to elucidate the potential influence of NSAID on SCC.

Behavior of dairy cows changes considerably around parturition and is affected by parity and the degree of difficulty at calving. Because accurate prediction of the degree of calving difficulty is not possible until the cow is actually in labor, to assess activity patterns accounting for parity and calving ease, within each treatment group a subset of cows was randomly assigned to receive activity data loggers at the time of first treatment. Thus, one limitation of this study was the lack of baseline activity data before parturition. No difference in LB and LBD was observed during the first $7 \mathrm{~d}$ after parturition between treatments. However, ASP cows tended to have more STP compared with PLC cows, which agrees with a previous study (Mainau et al., 2014) in which PRIM cows treated with MEL after parturition had increased STP during the first 2 DIM compared with controls. Interestingly, regardless of treatment, we observed that DYS cows had fewer STP, higher LT and number of LB, and shorter LBD compared with EUT cows. Moreover, results from this study showed that PRIM cows displayed a reduction in LB and had more STP compared with MULT cows.

Similar to our results, Swartz et al. (2018) observed that regardless of anti-inflammatory treatment, cows that experienced DYS had fewer STP, greater number of LB, and longer LBD in the first days after calving

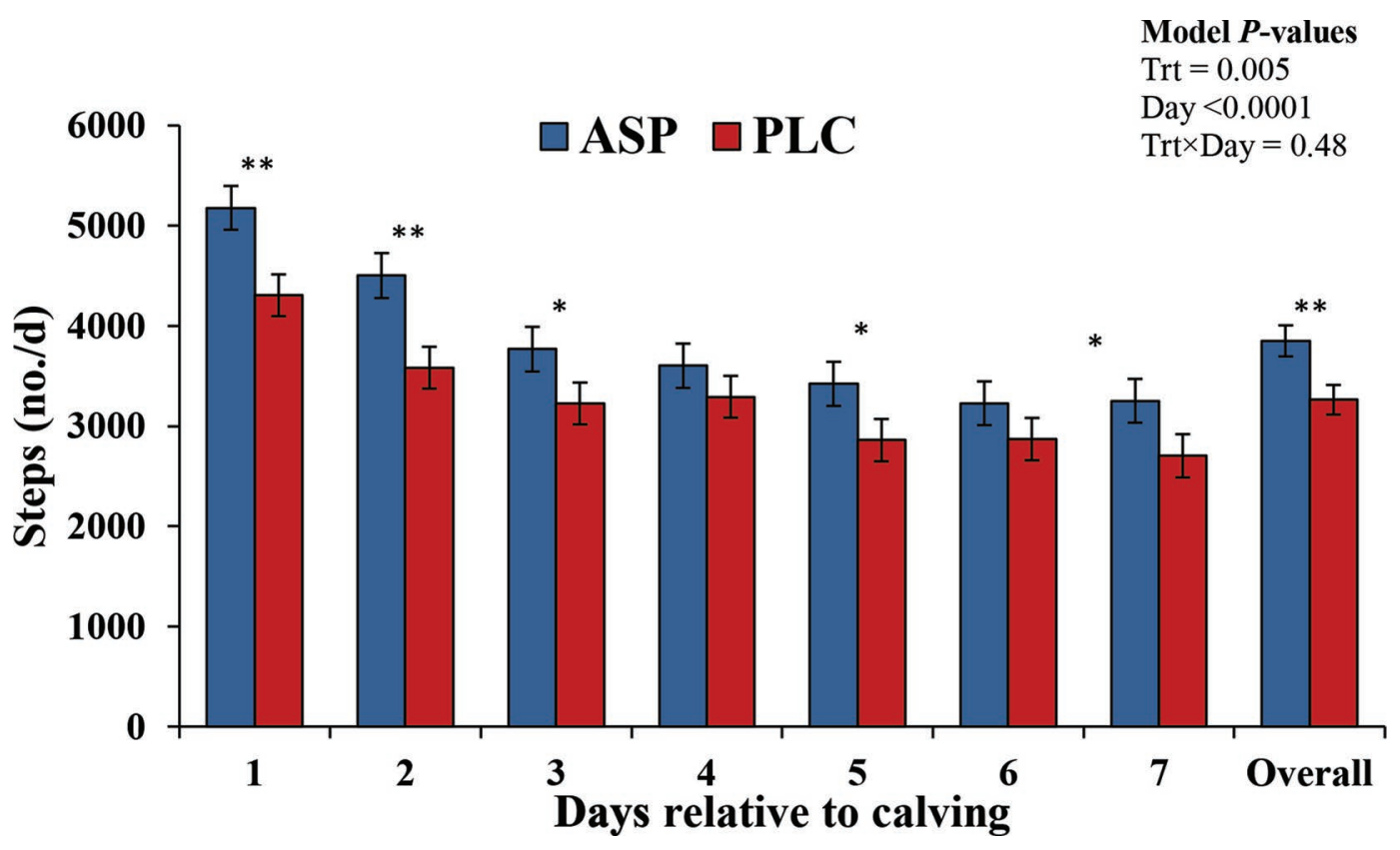

Figure 4. Steps (no./d) from calving (within $12 \mathrm{~h}$ of parturition) until 7 DIM for cows that received acetylsalicylic acid (ASP; $\mathrm{n}=36)$ or placebo $(\mathrm{PLC} ; \mathrm{n}=41)$ treatments. Values are presented as LSM \pm SEM. ${ }^{*} 0.05<P \leq 0.10 ;{ }^{* *} P<0.05$. $P$-values are from the "slice" option. Trt $=$ treatment. 
A
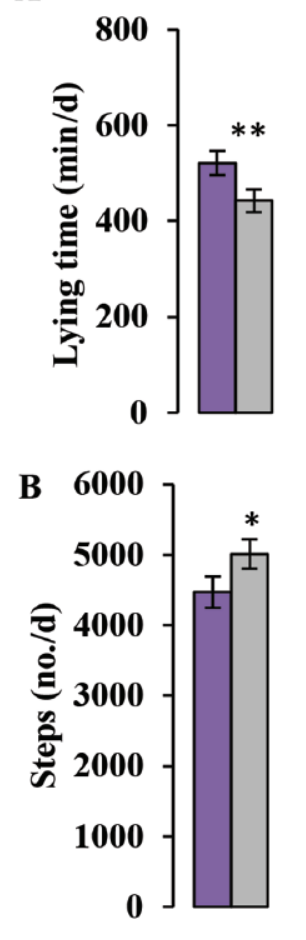

C

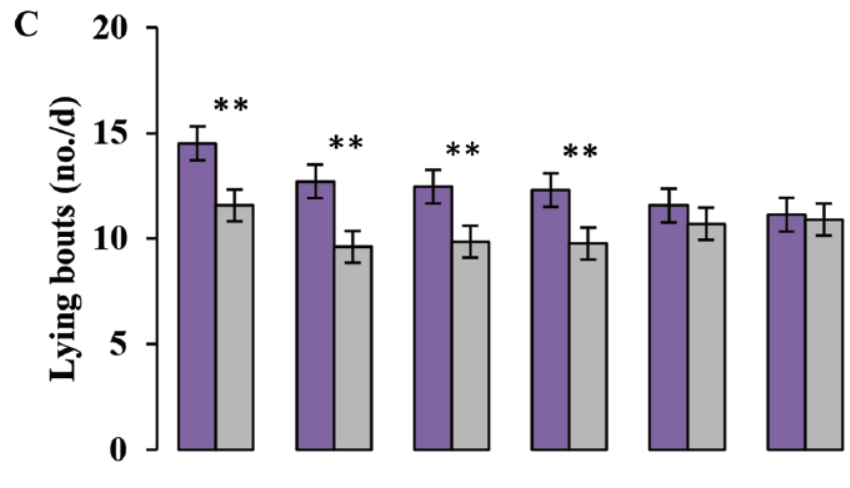

$\mathbf{D}$

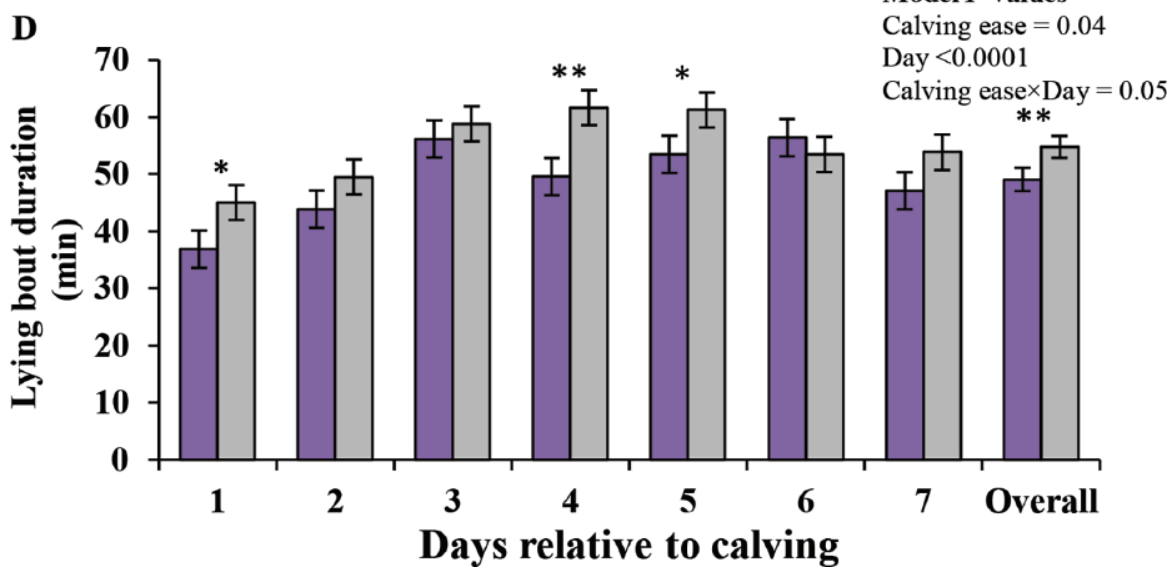

$$
\square \text { DYS } \square \text { EUT } \quad \begin{aligned}
& \text { Day }<0.0001 \\
& \text { Calving ease } \times \text { Day }=0.48
\end{aligned}
$$

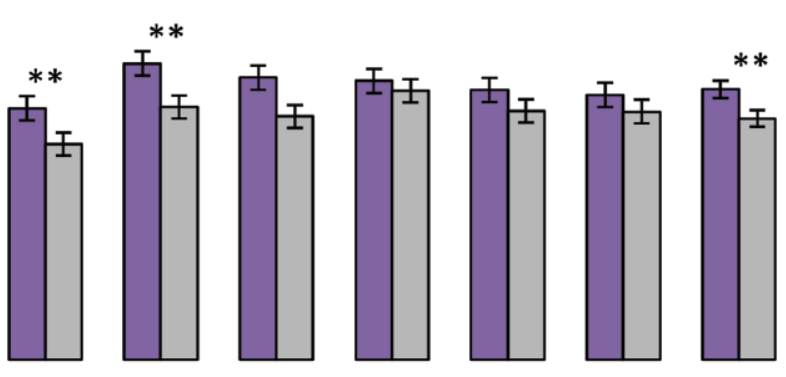

Model $\boldsymbol{P}$-values

Calving ease $=0.03$

Day $<0.0001$

Calving ease $\times$ Day $=0.95$
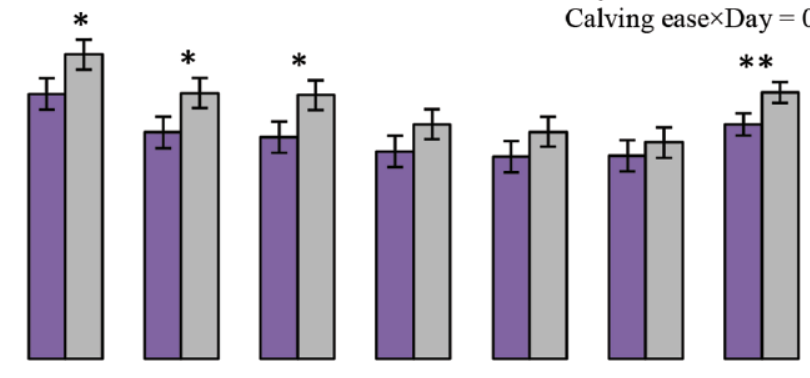

Model $\boldsymbol{P}$-values

Calving ease $=0.01$

Day $=0.002$

Calving ease $\times$ Day $=0.31$

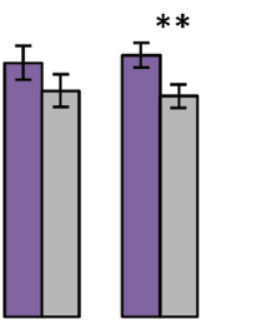

Model $\boldsymbol{P}$-values

Calving ease $=0.04$

Day $<0.000$

$* *$
Model $\boldsymbol{P}$-values

Calving ease $=0.01$

Day $<0.0001$ 
compared with cows with EUT births. Cows that experience DYS are more likely to suffer greater damage of the birth canal soft tissues compared with EUT cows (Farhoodi et al., 2000). It was reported that vulvovaginal laceration (Vieira-Neto et al., 2016) and HP concentrations in MULT cows by 5 DIM (Pohl et al., 2015) were positively correlated with DYS in dairy cows, suggesting that DYS cows experience more trauma and inflammation. In agreement with our study, it has been reported that PRIM cows had reduced LT and increased STP compared with MULT cows (Piñeiro et al., 2019). Thus, along with tissue damage-associated pain, cows that experience DYS will likely have higher circulating concentrations of mediators of inflammation compared with cows that calve spontaneously. Proinflammatory cytokines (IL-1, IL-6, and tumor necrosis factor- $\alpha$ ) and prostaglandins play a key role in the expression of sickness behaviors such as lethargy and depression that are observed during inflammatory states (Pecchi et al., 2009; Kuhla, 2020). Hence, treatment with NSAID could lead to a reduction of these soluble mediators of inflammation, hence ameliorating these behaviors associated with sickness and mitigating the pain associated with DYS calvings.

The transition period is characterized by a series of homeostatic and homeorhetic changes aimed to support the onset of milk synthesis and maintenance of the cow (Bradford et al., 2015; Baumgard et al., 2017). Nevertheless, the energy requirements will exceed the dietary energy intake, and cows enter a state of negative energy balance (Drackley, 1999). Furthermore, postpartum cows experience a transient peripheral insulin insensitivity state that diverts most of the glucose to the mammary gland for milk synthesis with the result-

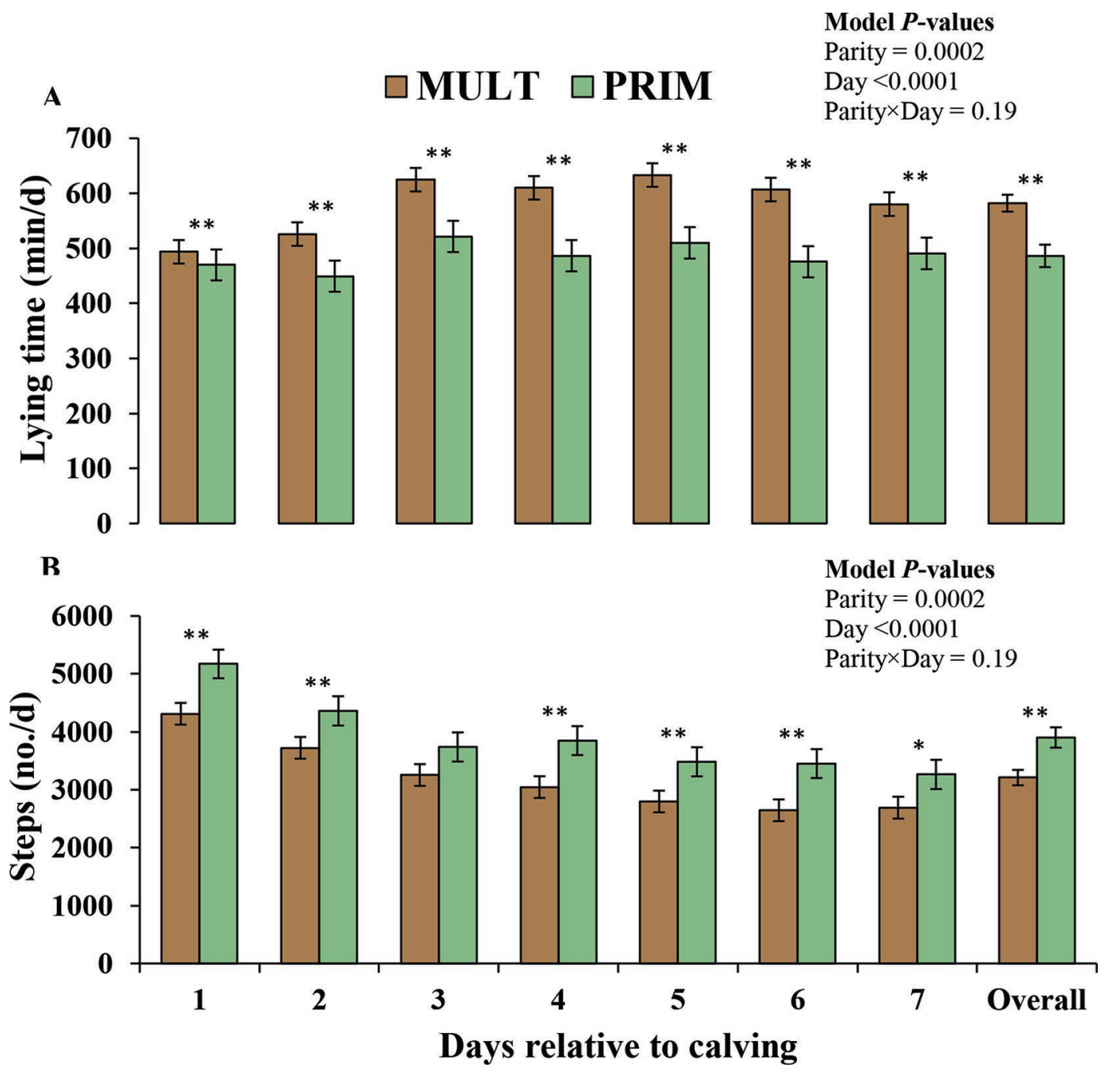

Figure 6. Daily (A) standing time (min/d) and (B) lying time (min/d) from calving (within $12 \mathrm{~h}$ of parturition) until 7 DIM for multiparous cows (MULT; $\mathrm{n}=48$ ) and primiparous cows (PRIM; $\mathrm{n}=29$ ). Values are presented as $\mathrm{LSM} \pm \mathrm{SEM}$. ${ }^{*} 0.05<P \leq 0.10 ; * * P<0.05 . P$-values are from the "slice" option. 
ing hypoglycemia (Bradford et al., 2015). Thus, cows will rely on fat mobilization as a source of energy. The inflammatory state experienced by postpartum cows and the increased circulating fatty acids concentrations have been linked to insulin insensitivity (Bradford et al., 2015). Although BHB concentrations did not differ between treatment groups on study d 7 and 14, cows treated with ASP had greater BCS at 7 and 14 DIM compared with PLC cows. Previous studies (Newby et al., 2013, 2017; Pascottini et al., 2020) that failed to find differences in milk production in cows treated with NSAID and controls reported no differences in feed intake, BCS, or BHB between groups. However, in other studies where increased milk production was observed (Bertoni et al., 2004; Farney et al., 2013a,b) that found increases in milk production in NSAID-treated animals, treated animals had increased BHB concentrations and lower BCS compared with control animals. This suggests that NSAID-treated cows mobilized more body reserves to produce the higher milk yields observed in these studies. In the present study, however, although increased milk production was observed, ASP-treated cows lost less BCS between first treatment administration and 14 DIM. Thus, modulation of inflammation with ASP could have resulted in less energy directed to the immune system and more nutrients available for maintenance and milk production. Similar to our findings, Barragan et al. (2019a) observed an improvement in the metabolic status (lower BHB concentration) of cows treated with ASP for $2 \mathrm{~d}$ after calving. Further research is needed to assess the effects of short NSAID administration after calving on the metabolic status of dairy cows.

In the present study, treated cows tended to have less DIMFS, DIMC, and SPC than PLC cows. Furthermore, an interaction between parity and treatment was observed, and MULT cows treated with ASP tended to have greater PAI at first service than PLC cows. Similar results were observed by Bertoni et al. (2004), who reported that a greater proportion of cows treated with sodium salicylate for $5 \mathrm{~d}$ after parturition became pregnant after first insemination, required less SPC, and had fewer days open compared with controls. More recently, Barragan et al. (2019b) reported that treating cows with aspirin for $2 \mathrm{~d}$ after calving resulted in lower incidence of uterine diseases (i.e., metritis, endometritis) and less DIMC and SPC. However, other authors (Farney et al., 2013b; Carpenter et al., 2016) reported no differences or negative effects of treatment with aspirin (Farney et al., 2013b) on cow fertility. Bertoni et al. (2008) observed that cows with lower inflammation after calving had reduced incidence of metritis and fewer days open and tended to require fewer services to become pregnant. Supporting the latter, Cheong et al. (2017) observed that regardless of uterine bacterial contamination, resumption of ovarian cyclicity started earlier in cows with lower circulating HP concentrations in the first 3 DIM and concluded that systemic inflammation was detrimental for resumption of cyclicity.

It has been reported that long $(7 \mathrm{~d})$ treatment with NSAID after calving may affect the metabolic status of cows, increasing concentration of BHB (Farney et

Table 3. Distribution (LSM \pm SEM) of BCS, BHB circulating concentrations, and proportion of cows with pyrexia and subclinical ketosis between cows treated with acetylsalicylic acid (ASP) or placebo (PLC)

\begin{tabular}{|c|c|c|c|c|c|c|}
\hline \multirow[b]{2}{*}{ Variable } & \multirow[b]{2}{*}{ Time } & \multicolumn{2}{|c|}{ Treatment $^{1}$} & \multicolumn{3}{|c|}{$P$-value } \\
\hline & & $\begin{array}{c}\text { ASP } \\
(\mathrm{n}=223)\end{array}$ & $\begin{array}{c}\text { PLC } \\
(\mathrm{n}=241)\end{array}$ & Treatment & Time & $\begin{array}{l}\text { Treatment } \\
\quad \times \text { time }\end{array}$ \\
\hline \multirow{2}{*}{$\overline{\mathrm{BCS}^{2}}$} & $7 \mathrm{~d}$ & $2.74 \pm 0.06$ & $2.66 \pm 0.06$ & - & - & - \\
\hline & $14 \mathrm{~d}$ & $2.64 \pm 0.06$ & $2.54 \pm 0.06$ & - & - & - \\
\hline \multirow[t]{2}{*}{ Pyrexia $^{3}(\%)$} & $12 \mathrm{~h}$ & $3.86 \pm 1.34$ & $3.63 \pm 1.26$ & 0.90 & - & - \\
\hline & $48 \mathrm{~h}$ & $5.77 \pm 1.99$ & $8.78 \pm 2.35$ & 0.33 & - & - \\
\hline \multirow[t]{2}{*}{$\mathrm{BHB}^{4}(\mathrm{mmol} / \mathrm{L})$} & $7 \mathrm{~d}$ & $0.95 \pm 0.09$ & $0.97 \pm 0.10$ & 0.90 & $<0.0001$ & 0.63 \\
\hline & $14 \mathrm{~d}$ & $0.73 \pm 0.10$ & $0.72 \pm 0.10$ & - & - & - \\
\hline \multirow{2}{*}{ Subclinical ketosis ${ }^{5}(\%)$} & $7 \mathrm{~d}$ & $16.59 \pm 3.90$ & $16.92 \pm 3.96$ & 0.92 & - & - \\
\hline & $14 \mathrm{~d}$ & $4.83 \pm 2.06$ & $4.54 \pm 2.40$ & 0.82 & - & - \\
\hline
\end{tabular}

${ }^{1}$ Data are presented as LSM \pm SEM.

${ }^{2}$ BCS was assessed using a 5-point scale (Ferguson et al., 1994) on study d 1 ( $\sim 12$ h after parturition), d 7 (7 \pm 3 DIM), and d 14 (14 \pm 3 DIM). ${ }^{3}$ Rectal temperature was assessed right before each treatment at approximately 12, 24, 36, and $48 \mathrm{~h}$ after parturition. Pyrexia was defined as rectal temperature $\geq 39.5 \mathrm{C}^{\circ}$.

${ }^{4}$ Blood BHB concentration was evaluated on $\mathrm{d} 7$ and 14 .

${ }^{5}$ Blood BHB concentration $>1.2 \mathrm{mmol} / \mathrm{L}$ (Iwersen et al., 2009). 


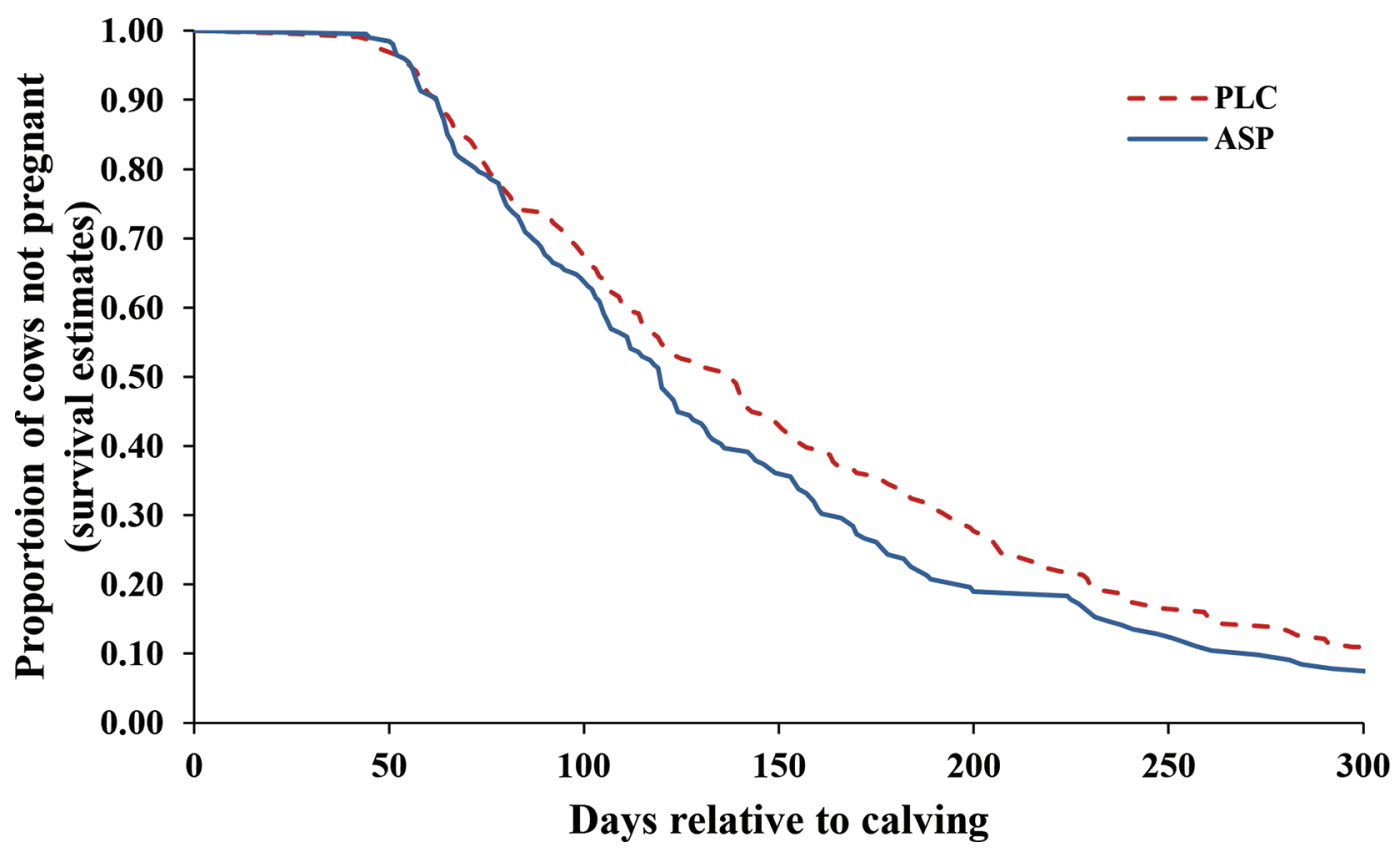

Figure 7. Survival curve for time to pregnancy after the voluntary waiting period of dairy cows treated with acetylsalicylic acid $($ ASP; $\mathrm{n}=$ 223) compared with cows that received a placebo $(\mathrm{PLC} ; \mathrm{n}=241)$. The adjusted hazard ratio (AHR 95\% CI) for pregnancy $(P=0.06)$ was 1.22 for ASP cows (referent = PLC cows). Mean time to pregnancy was $147 \mathrm{~d}(140-154 \mathrm{~d})$ and $170 \mathrm{~d}(162-178 \mathrm{~d})$ for ASP and PLC cows, respectively.

al., 2013a). The negative effects of a high concentration of BHB on uterine health and cow fertility are well documented (Walsh et al., 2007; LeBlanc, 2010; Ribeiro et al., 2013). Carvalho et al. (2014) observed that cows that lost BCS in the first 21 DIM had lower PAI at 70 postinsemination compared with cows that maintained or gained BCS. Although no differences in the proportion of cows with ketosis or circulating concentrations of BHB were observed, cows treated with ASP tended to and had higher BCS on study d 7 and 14, respectively. As opposed to immune function and milk production, fewer nutrients are directed toward expendable processes such reproduction and fat deposition in early-postpartum cows (Johnson, 1997; Baumgard et al., 2017). Thus, treatment with ASP might increase the energy available for fat deposition and fertility.

\section{CONCLUSIONS}

Similar to other studies that evaluated the effects of treatment with NSAID on performance of dairy cows, we observed a beneficial effect of administering ASP to dairy cows during the early-postpartum period. Results from the present study suggest that a short-duration treatment with acetylsalicylic acid after parturition

Table 4. Proportion (\%) of retention of fetal membranes, cases of disease, culling, and mortality during the first 60 DIM in cows treated with acetylsalicylic acid (ASP) compared with cows that received a placebo $(\mathrm{PLC})^{1}$

\begin{tabular}{|c|c|c|c|}
\hline \multirow[b]{2}{*}{ Variable } & \multicolumn{2}{|c|}{ Treatment } & \multirow[b]{2}{*}{$P$-value } \\
\hline & $\begin{array}{c}\text { ASP } \\
(\mathrm{n}=223)\end{array}$ & $\begin{array}{c}\text { PLC } \\
(\mathrm{n}=241)\end{array}$ & \\
\hline Retention of fetal membranes $^{2}$ & $7.79 \pm 1.81$ & $9.24 \pm 1.88$ & 0.58 \\
\hline No health events & $55.86 \pm 9.04$ & $58.55 \pm 8.95$ & 0.60 \\
\hline Single clinical disease event ${ }^{3}$ & $33.51 \pm 7.65$ & $27.99 \pm 7.05$ & 0.27 \\
\hline Multiple clinical disease events ${ }^{3}$ & $6.97 \pm 2.28$ & $8.59 \pm 2.61$ & 0.49 \\
\hline Culling $^{3}$ & $38.56 \pm 3.26$ & $32.92 \pm 3.04$ & 0.20 \\
\hline Mortality $^{3}$ & $3.69 \pm 1.58$ & $2.10 \pm 1.10$ & 0.37 \\
\hline
\end{tabular}

${ }^{1}$ Data are presented as LSM \pm SEM.

${ }^{2}$ Considered to be failure to expel the placenta within $24 \mathrm{~h}$ after parturition.

${ }^{3}$ Recorded by farm personnel and obtained from the on-farm computer records. 
may enhance milk production, reduce SCC, alter activity patterns, and improve fertility of lactating cows. More research is required to confirm these findings and elucidate the potential mechanisms by which treating dairy cows with NSAID in the early postpartum period could lead to an improved performance throughout the lactation.

\section{ACKNOWLEDGMENTS}

The authors thank the farm owners and personnel from the dairy operations that participated in this study for the help provided to the research team and for allowing the use of their animals and facilities to perform this project. We also acknowledge Ohio Dairy Producers Association (Columbus, $\mathrm{OH}$ ) for providing partial funding for this study. The authors have not stated any conflicts of interest.

\section{REFERENCES}

Barragan, A. A., S. Bas, E. Hovingh, A. Ludwikowski, S. Takitch, J. Zug, and S. Hann. 2019a. Effects of a new preventive strategy with acetylsalicylic acid on metabolic status and inflammation in dairy cows after calving. J. Dairy Sci. 102:180-181. (Abstr.)

Barragan, A. A., S. Bas, E. Hovingh, A. Ludwikowski, S. Takitch, J. Zug, and S. Hann. 2019b. Effects of a new preventive strategy with acetylsalicylic acid on uterine diseases and reproductive performance in dairy cows. J. Dairy Sci. 102:308. (Abstr.)

Barragan, A. A., J. M. Piñeiro, G. M. Schuenemann, P. J. RajalaSchultz, D. E. Sanders, J. Lakritz, and S. Bas. 2018. Assessment of daily activity patterns and biomarkers of pain, inflammation, and stress in lactating dairy cows diagnosed with clinical metritis. J. Dairy Sci. 101:8248-8258. https://doi.org/10.3168/jds.2018-14510.

Battini, M., A. Vieira, S. Barbieri, I. Ajuda, G. Stilwell, and S. Mattiello. 2014. Invited review: Animal-based indicators for on-farm welfare assessment for dairy goats. J. Dairy Sci. 97:6625-6648. https://doi.org/10.3168/jds.2013-7493.

Baumgard, L. H., R. J. Collier, and D. E. Bauman. 2017. A 100-year review: Regulation of nutrient partitioning to support lactation. J. Dairy Sci. 100:10353-10366. https://doi.org/10.3168/jds.2017 -13242 .

Bertoni, G., E. Trevisi, X. Han, and M. Bionaz. 2008. Effects of inflammatory conditions on liver activity in puerperium period and consequences for performance in dairy cows. J. Dairy Sci. 91:33003310. https://doi.org/10.3168/jds.2008-0995.

Bertoni, G., E. Trevisi, and F. Piccioli-Cappelli. 2004. Effects of acetyl-salicylate used in post-calving of dairy cows. Vet. Res. Commun. 28:217-219. https://doi.org/10.1023/B:VERC.0000045410 86004.03 .

Bionaz, M., E. Trevisi, L. Calamari, F. Librandi, A. Ferrari, and G. Bertoni. 2007. Plasma paraoxonase, health, inflammatory conditions, and liver function in transition dairy cows. J. Dairy Sci. 90:1740-1750. https://doi.org/10.3168/jds.2006-445.

Bradford, B. J., K. Yuan, J. K. Farney, L. K. Mamedova, and A. J. Carpenter. 2015. Invited review: Inflammation during the transition to lactation: New adventures with an old flame. J. Dairy Sci. 98:6631-6650. https://doi.org/10.3168/jds.2015-9683.

Caldeira, M. O., R. M. Bruckmaier, and O. Wellnitz. 2019. Meloxicam affects the inflammatory responses of bovine mammary epithelial cells. J. Dairy Sci. 102:10277-10290. https://doi.org/10.3168/jds .2019-16630.

Carpenter, A. J., C. M. Ylioja, C. F. Vargas, L. K. Mamedova, L. G. Mendonça, J. F. Coetzee, L. C. Hollis, R. Gehring, and B. J. Brad- ford. 2016. Hot topic: Early postpartum treatment of commercial dairy cows with nonsteroidal antiinflammatory drugs increases whole-lactation milk yield. J. Dairy Sci. 99:672-679. https://doi .org/10.3168/jds.2015-10048.

Carvalho, P. D., A. H. Souza, M. C. Amundson, K. S. Hackbart, M. J. Fuenzalida, M. M. Herlihy, H. Ayres, A. R. Dresch, L. M. Vieira J. N. Guenther, R. R. Grummer, P. M. Fricke, R. D. Shaver, and M. C. Wiltbank. 2014. Relationships between fertility and postpartum changes in body condition and body weight in lactating dairy cows. J. Dairy Sci. 97:3666-3683. https://doi.org/10.3168/ jds.2013-7809.

Cheong, S. H., O. G. Sa Filho, V. A. Absalon-Medina, A. Schneider, W. R. Butler, and R. O. Gilbert. 2017. Uterine and systemic inflammation influences ovarian follicular function in postpartum dairy cows. PLoS One 12:e0177356. https://doi.org/10.1371/ journal.pone.0177356.

Coetzee, J. F. 2013. A review of analgesic compounds used in food animals in the United States. Vet. Clin. North Am. Food Anim. Pract. 29:11-28. https://doi.org/10.1016/j.cvfa.2012.11.008.

Connelly, L., W. Barham, R. Pigg, L. Saint-Jean, T. Sherrill, D.-S. Cheng, L. A. Chodosh, T. S. Blackwell, and F. E. Yull. 2010. Activation of nuclear factor kappa B in mammary epithelium promotes milk loss during mammary development and infection. J. Cell. Physiol. 222:73-81. https://doi.org/10.1002/jcp.21922.

Domecq, J. J., A. L. Skidmore, J. W. Lloyd, and J. B. Kaneene. 1997. Relationship between body condition scores and milk yield in a large dairy herd of high yielding Holstein cows. J. Dairy Sci 80:101-112. https://doi.org/10.3168/jds.S0022-0302(97)75917-4.

Drackley, J. K. 1999. ADSA Foundation Scholar Award. Biology of dairy cows during the transition period: The final frontier? J. Dairy Sci. 82:2259-2273. https://doi.org/10.3168/jds.S0022 -0302(99)75474-3.

Farhoodi, M., I. Nowrouzian, P. Hovareshti, M. Bolourchi, and M. G. Nadalian. 2000. Factors associated with rectovaginal injuries in Holstein dairy cows in a herd in Tehran, Iran. Prev. Vet. Med. 46:143-148. https://doi.org/10.1016/S0167-5877(00)00129-X.

Farney, J. K., L. K. Mamedova, J. F. Coetzee, B. KuKanich, L. M. Sordillo, S. K. Stoakes, J. E. Minton, L. C. Hollis, and B. J. Bradford. 2013a. Anti-inflammatory salicylate treatment alters the metabolic adaptations to lactation in dairy cattle. Am. J. Physiol 305:R110-R117. https://doi.org/10.1152/ajpregu.00152.2013.

Farney, J. K., L. K. Mamedova, J. F. Coetzee, J. E. Minton, L. C. Hollis, and B. J. Bradford. 2013b. Sodium salicylate treatment in early lactation increases whole-lactation milk and milk fat yield in mature dairy cows. J. Dairy Sci. 96:7709-7718. https://doi.org/10 .3168/jds.2013-7088.

Ferguson, J. D., D. T. Galligan, and N. Thomsen. 1994. Principal descriptors of body condition score in Holstein cows. J. Dairy Sci. 77:2695-2703. https://doi.org/10.3168/jds.S0022-0302(94)77212 $-\mathrm{X}$.

Huxley, J. N., and H. R. Whay. 2006. Current attitudes of cattle practitioners to pain and the use of analgesics in cattle. Vet. Rec. 159:662-668. https://doi.org/10.1136/vr.159.20.662.

Iwersen, M., U. Falkenberg, R. Voigtsberger, D. Forderung, and W. Heuwieser. 2009. Evaluation of an electronic cowside test to detect subclinical ketosis in dairy cows. J. Dairy Sci. 92:2618-2624. https: //doi.org/10.3168/jds.2008-1795.

Johnson, R. W. 1997. Inhibition of growth by pro-inflammatory cytokines: An integrated view. J. Anim. Sci. 75:1244-1255. https://doi .org/10.2527/1997.7551244x.

Kelton, D. F., K. D. Lissemore, and R. E. Martin. 1998. Recommendations for recording and calculating the incidence of selected clinical diseases of dairy cattle. J. Dairy Sci. 81:2502-2509.

Knight, C. H., and M. Peaker. 1982. Development of the mammary gland. J. Reprod. Fertil. 65:521-536. https://doi.org/10.1530/jrf 0.0650521 .

Kutuk, O., and H. Basaga. 2004. Aspirin inhibits TNF- $\alpha$ and IL-1 induced NFkB activation and sensitizes HeLa cells to apoptosis. Cytokine 25:229-237. https://doi.org/10.1016/j.cyto.2003.11.007.

Kuhla, B. 2020. Review: Pro-inflammatory cytokines and hypothalamic inflammation: Implications for insufficient feed intake of transi- 
tion dairy cows. Animal 14(Suppl. 1):s65-s77. https://doi.org/10 $1017 /$ S1751731119003124.

Laven, R. A., J. N. Huxley, H. R. Whay, and K. J. Stafford. 2009. Results of a survey of attitudes of dairy veterinarians in New Zealand regarding painful procedures and conditions in cattle. N. Z. Vet. J. 57:215-220. https://doi.org/10.1080/00480169.2009.36904.

Laven, R. A., and A. R. Peters. 1996. Bovine retained placenta: Aetiology, pathogenesis, and economic loss. Vet. Rec. 139:465-471. https://doi.org/10.1136/vr.139.19.465.

LeBlanc, S. 2010. Monitoring metabolic health of dairy cattle in the transition period. J. Reprod. Dev. 56(Suppl.):S29-S35. https://doi .org/10.1262/jrd.1056S29.

Lombard, J. E., F. B. Garry, S. M. Tomlinson, and L. P. Garber. 2007. Impacts of dystocia on health and survival of dairy calves. J. Dairy Sci. 90:1751-1760. https://doi.org/10.3168/jds.2006-295.

Mainau, E., A. Cuevas, J. L. Ruiz-de-la-Torre, E. Abbeloos, and X. Manteca. 2014. Effect of meloxicam administration after calving on milk production, acute phase proteins, and behavior in dairy cows. J. Vet. Behav. Clin. Appl. Res. 9:357-363. https://doi.org/ 10.1016/j.jveb.2014.07.007.

McCarthy, M. M., T. Yasui, M. J. B. Felippe, and T. R. Overton. 2016. Associations between the degree of early lactation inflammation and performance, metabolism, and immune function in dairy cows. J. Dairy Sci. 99:680-700. https://doi.org/10.3168/jds.2015-9694.

McDougall, S., M. A. Bryan, and R. M. Tiddy. 2009. Effect of treatment with the nonsteroidal antiinflammatory meloxicam on milk production, somatic cell count, probability of re-treatment, and culling of dairy cows with mild clinical mastitis. J. Dairy Sci. 92:4421-4431. https://doi.org/10.3168/jds.2009-2284.

Mee, J. F. 2008. Prevalence and risk factors for dystocia in dairy cattle: A review. Vet. J. 176:93-101. https://doi.org/10.1016/j.tvjl .2007.12.032.

Meier, S., N. V. Priest, C. R. Burke, J. K. Kay, S. McDougall, M. D. Mitchell, C. G. Walker, A. Heiser, J. J. Loor, and J. R. Roche. 2014. Treatment with a nonsteroidal antiinflammatory drug after calving did not improve milk production, health, or reproduction parameters in pasture-grazed dairy cows. J. Dairy Sci. 97:29322943. https://doi.org/10.3168/jds.2013-7838.

Newby, N. C., K. E. Leslie, H. D. P. Dingwell, D. F. Kelton, D. M. Weary, L. Neuder, S. T. Millman, and T. F. Duffield. 2017. The effects of periparturient administration of flunixin meglumine on the health and production of dairy cattle. J. Dairy Sci. 100:582-587. https://doi.org/10.3168/jds.2016-11747.

Newby, N. C., D. L. Pearl, S. J. LeBlanc, K. E. Leslie, M. A. G. von Keyserlingk, and T. F. Duffield. 2013. Effects of meloxicam on milk production, behavior, and feed intake in dairy cows following assisted calving. J. Dairy Sci. 96:3682-3688. https://doi.org/ $10.3168 /$ jds.2012-6214.

NRC. 2001. Nutrient Requirements of Dairy Cattle. 7th rev. ed. Natl. Acad. Sci., Washington, DC.

Pascottini, O. B., S. J. Van Schyndel, J. F. W. Spricigo, M. R. Carvalho, B. Mion, E. S. Ribeiro, and S. J. LeBlanc. 2020. Effect of anti-inflammatory treatment on systemic inflammation, immune function, and endometrial health in postpartum dairy cows. Sci. Rep. 10:5236. https://doi.org/10.1038/s41598-020-62103-x.

Pecchi, E., M. Dallaporta, A. Jean, S. Thirion, and J. D. Troadec. 2009. Prostaglandins and sickness behavior: Old story, new insights. Physiol. Behav. 97:279-292. https://doi.org/10.1016/j .physbeh.2009.02.040.

Piñeiro, J. M., B. T. Menichetti, A. A. Barragan, A. E. Relling, W. P. Weiss, S. Bas, and G. M. Schuenemann. 2019. Associations of pre- and postpartum lying time with metabolic, inflammation, and health status of lactating dairy cows. J. Dairy Sci. 102:3348-3361. https://doi.org/10.3168/jds.2018-15386.

Pohl, A., O. Burfeind, and W. Heuwieser. 2015. The associations between postpartum serum haptoglobin concentration and metabolic status, calving difficulties, retained fetal membranes, and metritis. J. Dairy Sci. 98:4544-4551. https://doi.org/10.3168/jds.2014-9181.

Proudfoot, K. L., J. M. Huzzey, and M. A. G. Von Keyserlingk. 2009. The effect of dystocia on the dry matter intake and behavior of Holstein cows. J. Dairy Sci. 92:4937-4944. https://doi.org/10 $.3168 /$ jds.2009-2135.

Remnant, J. G., A. Tremlett, J. N. Huxley, and C. D. Hudson. 2017. Clinician attitudes to pain and use of analgesia in cattle: Where are we 10 years on? Vet. Rec. 181:400-1-400-7. https://doi.org/10 $.1136 /$ vr.104428.

Ribeiro, E. S., F. S. Lima, L. F. Greco, R. S. Bisinotto, A. P. A. Monteiro, M. Favoreto, H. Ayres, R. S. Marsola, N. Martinez, W. W. Thatcher, and J. E. P. Santos. 2013. Prevalence of periparturient diseases and effects on fertility of seasonally calving grazing dairy cows supplemented with concentrates. J. Dairy Sci. 96:5682-5697. https://doi.org/10.3168/jds.2012-6335.

Santos, J. E. P., R. S. Bisinotto, E. S. Ribeiro, F. S. Lima, L. F. Greco, C. R. Staples, W. W. Thatcher, M. F. Smith, M. C. Lucy, and J. L. Pate. 2011. Applying nutrition and physiology to improve reproduction in dairy cattle. Reprod. Domest. Rumin. 7:387-403.

Schuenemann, G. M., I. Nieto, S. Bas, K. N. Galvão, and J. Workman. 2011. Assessment of calving progress and reference times for obstetric intervention during dystocia in Holstein dairy cows. J. Dairy Sci. 94:5494-5501. https://doi.org/10.3168/jds.2011-4436.

Sheldon, I. M., E. J. Williams, A. N. Miller, D. M. Nash, and S. Herath. 2008. Uterine diseases in cattle after parturition. Vet. J. 176:115-121. https://doi.org/10.1016/j.tvjl.2007.12.031.

Smith, G. W., J. L. Davis, L. A. Tell, A. I. Webb, and J. E. Riviere. 2008. Extralabel use of nonsteroidal anti-inflammatory drugs in cattle. J. Am. Vet. Med. Assoc. 232:697-701. https://doi.org/10 $.2460 /$ javma.232.5.697.

Sordillo, L. M., G. A. Contreras, and S. L. Aitken. 2009. Metabolic factors affecting the inflammatory response of periparturient dairy cows. Anim. Health Res. Rev. 10:53-63. https://doi.org/10.1017/ S1466252309990016.

Swartz, T. H., H. H. Schramm, J. M. Bewley, C. M. Wood, K. E. Leslie, and C. S. Petersson-Wolfe. 2018. Meloxicam administration either prior to or after parturition: Effects on behavior, health, and production in dairy cows. J. Dairy Sci. 101:10151-10167. https:// doi.org/10.3168/jds.2018-14657.

Trevisi, E., and G. Bertoni. 2008. Attenuation with acetylsalicylate treatments of inflammatory conditions in periparturient dairy cows. Pages 22-37 in Aspirin Health and Research Progress. P. I. Quinn, ed. Nova Science Publishers, Hauppauge, NY.

USDA. 2007. Dairy, 2007, Part IV: Reference of Dairy Cattle Health and Management Practices in the United States. USDA/APHIS/ VS/CEAH, Fort Collins, CO.

USDA. 2014. Dairy, 2014. Health and Management Practices on U.S. Dairy Operations. USDA/APHIS/VS/CEAH, Fort Collins, CO.

Van Nuffel, A., I. Zwertvaegher, L. Pluym, S. Van Weyenberg, V. M. Thorup, M. Pastell, B. Sonck, and W. Saeys. 2015. Lameness detection in dairy cows: Part 1 . How to distinguish between non-lame and lame cows based on differences in locomotion or behavior. Animals (Basel) 5:838-860. https://doi.org/10.3390/ani5030387.

Vane, J. R., and R. M. Botting. 1997. Mechanism of action of aspirinlike drugs. Semin. Arthritis Rheum. 26(Suppl. 1).2-10.

Vieira-Neto, A., F. S. Lima, J. E. P. Santos, R. D. Mingoti, G. S. Vasconcellos, C. A. Risco, and K. N. Galvao. 2016. Vulvovaginal laceration as a risk factor for uterine disease in postpartum dairy cows. J. Dairy Sci. 99:4629-4637. https://doi.org/10.3168/jds.2016 -10872 .

Walsh, R. B., J. S. Walton, D. F. Kelton, S. J. LeBlanc, K. E. Leslie, and T. F. Duffield. 2007. The effect of subclinical ketosis in early lactation on reproductive performance of postpartum dairy cows J. Dairy Sci. 90:2788-2796. https://doi.org/10.3168/jds.2006-560. 